Schoeb TR, Lindsey JR (1987) Exacerbation of murine respiratory mycoplasmosis by sialodacryoadenitis virus infection in gnotobiotic F344 rats. Vet Pathol 24:392-399

Schoeb TR, Kervin KC, Lindsey JR (1985) Exacerbation of murine respiratory mycoplasmosis in gnotobiotic $\mathrm{F} 344 / \mathrm{N}$ rats by Sendai virus infection. Vet Pathol 22:272-282

Schoeb TR, Dybvig K, Davidson MK, Davis JK (1993a) Cultivation of cilia-associated respiratory bacillus in artificial medium and determination of the 16S rRNA gene sequence. J Clin Microbiol 31:2751-2757

Schoeb TR, Juliana MM, Nichols PW, Davis JK, Lindsey JR (1993b) Effects of viral and mycoplasmal infections, ammonia exposure, vitamin A deficiency, host age, and organism strain on adherence of Mycoplasma pulmonis in cultured rat tracheas. Lab Anim Sci 43:417-424

Simecka JW, Patel P, Davis JK, Ross SE, Otwell P, Cassell, GH (1991) Specific and nonspecific antibody responses in different segments of the respiratory tract in rats infected with Mycoplasma pulmonis. Infect Immun 59:3715-3721

Simecka JW, Davis JK, Davidson MK, Ross SE, Stadtlander CTK, Cassell GH (1992) Mycoplasma diseases of animals. In: Maniloff J, McElhaney RN, Finch LE, Baseman JB (eds) Mycoplasmas: molecular biology and pathogenesis. American Society for Microbiology, Washington DC, chap 24

Simecka JW, Ross SE, Cassell GH, Davis JK (1993) Interactions of mycoplasmas with B cells: antibody production and nonspecific effects. Clin Infect Dis 17 [Suppl 1]:S176-S182

Steiner DA, Uhl EW, Brown MB (1993) In utero transmission of Mycoplasma pulmonis in experimentally infected Sprague-Dawley rats. Infect Immun 61:2985-2990

Stuart PM, Cassell GH, Woodward JG (1989) Induction of class II MHC antigen expression in macrophages by Mycoplasma species. J Immunol 142:3392-3399
Swing SP, Davis JK, Egan ML (1995) In vitro effects of Mycoplasma pulmonis on murine natural killer cell activity. Lab Anim Sci (in press)

Talkington DF, Fallon MT, Watson HL, Thorp RK, Cassell GH (1989) Mycoplasma pulmonis V-1 surface protein variation: occurrence in vivo and association with lung lesions. Microb Pathog 7:429-436

Taylor G, Taylor-Robinson D (1976) Effects of active and passive immunization on Mycoplasma pulmonis-induced pneumonia in mice. Immunology 30:611-618

Ursi JP, Ursi D, Ieven M, Pattyn SR (1992) Utility of an internal control for the polymerase chain reaction. Application to detection of Mycoplasma pneumoniae in clinical specimens. APMIS 100:635-639

van Kuppeveld FJ, van der Logt JT, Angulo AF, van Zoest MJ, Quint WG, Niesters HG, Galama JM, Melchers WJ (1992) Genus- and species-specific identification of mycoplasmas by 16S rRNA amplification. Appl Environ Microbiol 58:26062615 (published erratum appears in Appl Environ Microbiol 59: 655, 1993)

van Kuppeveld FJ, Melchers WJ, Willemse HF, Kissing J, Galama JM, van der Logt JT (1993) Detection of Mycoplasma pulmonis in experimentally infected laboratory rats by $16 \mathrm{~S}$ rRNA amplification. J Clin Microbiol 31:524527

Watson HL, McDaniel LS, Blalock DK, Fallon MT, Cassell GH (1988) Heterogeneity among strains and a high rate of variation within strains of a major surface antigen of Mycoplasma pulmonis. Infect Immun 56:1358-1363

Williamson JS, Davis JK, Cassell GH (1986) Polyclonal activation of rat splenic lymphocytes after in vivo administration of Mycoplasma pulmonis and its relation to in vitro response. Infect Immun 52:594-599

\title{
Rat Coronavirus Infection, Upper Respiratory Tract, Rat
}

\author{
David G. Brownstein
}

Synonyms. Rat submaxillary gland virus infection, sialodacryoadenitis virus, Parker's rat coronavirus

\section{Gross Appearance}

Gross lesions are usually extrarespiratory and limited to mixed or serous salivary glands, exorbital glands, harderian glands, periglandular connective tissue, cervical lymph nodes, and thymus. The submaxillary and parotid salivary glands are enlarged, pale, and edematous. Intermandibular and cervical connective tissue is gelatinous due to periglandular edema. This edema restricts the venous return in the neck, resulting in distention of the great veins entering the thoracic inlet. Exorbital glands are occasionally enlarged. Harderian glands are swollen and flecked with yellow-gray spots. These foci must be distinguished from normal brown-red mottling of the harderian gland imparted by its normal content of porphyrin pigment. The cervical lymph nodes are enlarged, and the thymus is atrophic. In these cases ocular lesions may include corneral opacity, corneal ulcers, pannus, hypopyon, hyphema, and megalogobus (Innes and Stanton 1961; Jacoby et al. 1975, 1979). 


\section{Microscopic Features}

Respiratory lesions are restricted primarily to the upper respiratory tract. They precede inflammatory changes in the exocrine tissues of the head. Over the course of approximately 5 days, beginning on the 2nd day of infection, there is spreading necrosis of respiratory epithelium in the nasal cavity accompanied by congestion, edema, and mixed inflammatory infiltrate of the lamina propria (Figs. 162, 163). The epithelial lining of the turbinates is most severely affected; olfactory epithelium is usually spared. Some meatuses are covered by exudate composed of necrotic epithelium, neutrophils, and mucus. Despite a tropism of these viruses for serous or mixed salivary glands the serous mucosal glands of the nasopharynx sustain relatively mild injury. Necrotic ducts and acini within mucosal glands do occur, however, and afford some specificity to the lesion. There is qualitatively similar inflammation in the trachea, but changes are milder and less uniform than in the nasopharynx. Upper respiratory lesions are resolved by the end of the 2nd week of infection. Lung changes are confined to mild hyperplasia within peribronchial lymphoid nodules (Jacoby et al. 1975, 1979).

Severe inflammatory changes occur within mixed or serous salivary glands, exorbital glands, and harderian glands. Description of these changes is beyond the scope of this volume. The reader is referred to several excellent studies of sequential changes in these tissues (Innes and Stanton 1961; Jacoby et al. 1975, 1979).

\section{Ultrastructure}

We have found no report of the ultrastructural features of respiratory tract lesions caused by rat coronavirus, but these features have been studied in infected submaxillary gland epithelium (Jonas
Fig. 162. Ventral turbinate and lateral wall of nasal cavity in rat experimentally infected with rat coronavirus. Note exudative inflammation of the mucosa with gaps in epithelial integrity. $\mathrm{H} \& \mathrm{E}, \times 240$

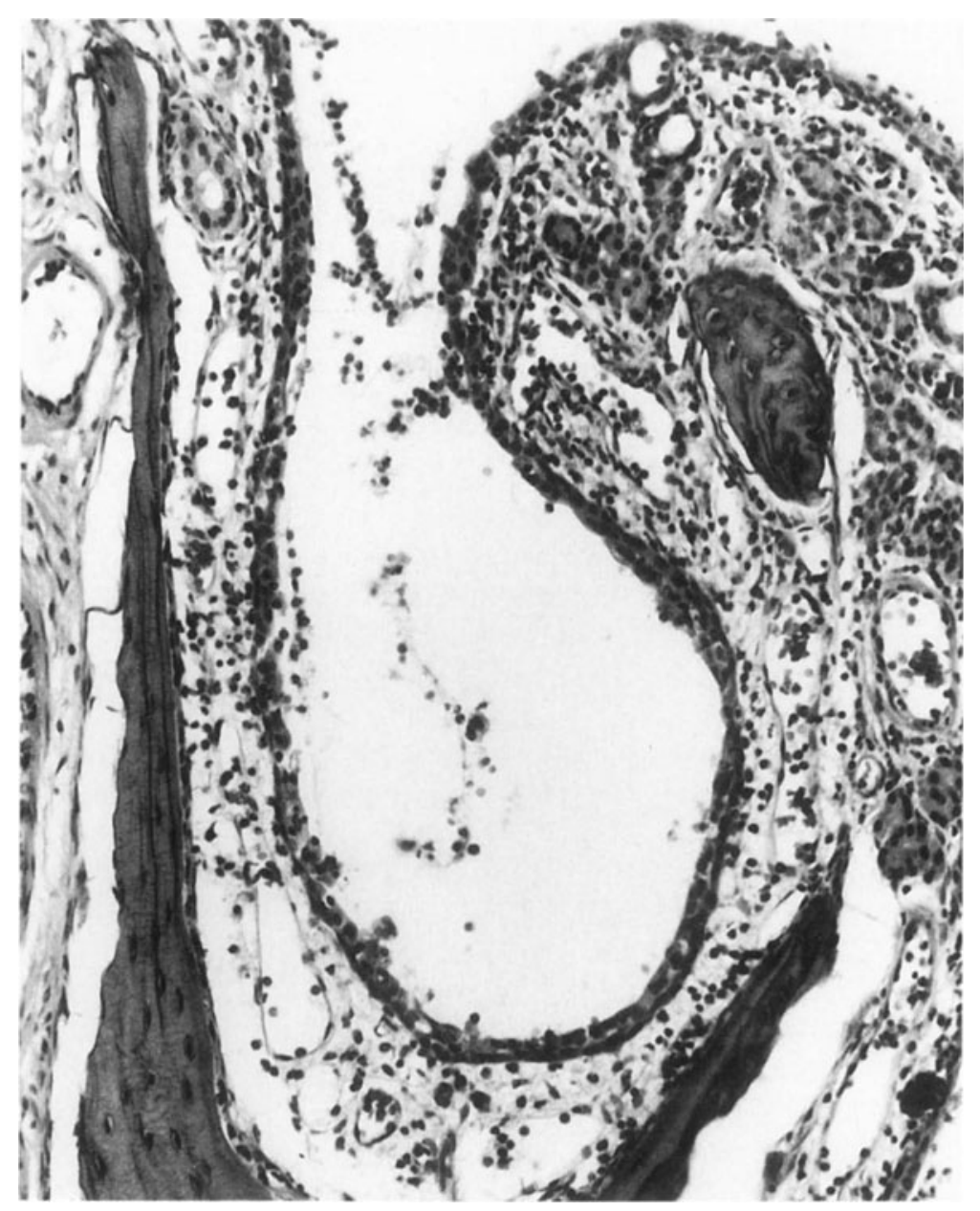




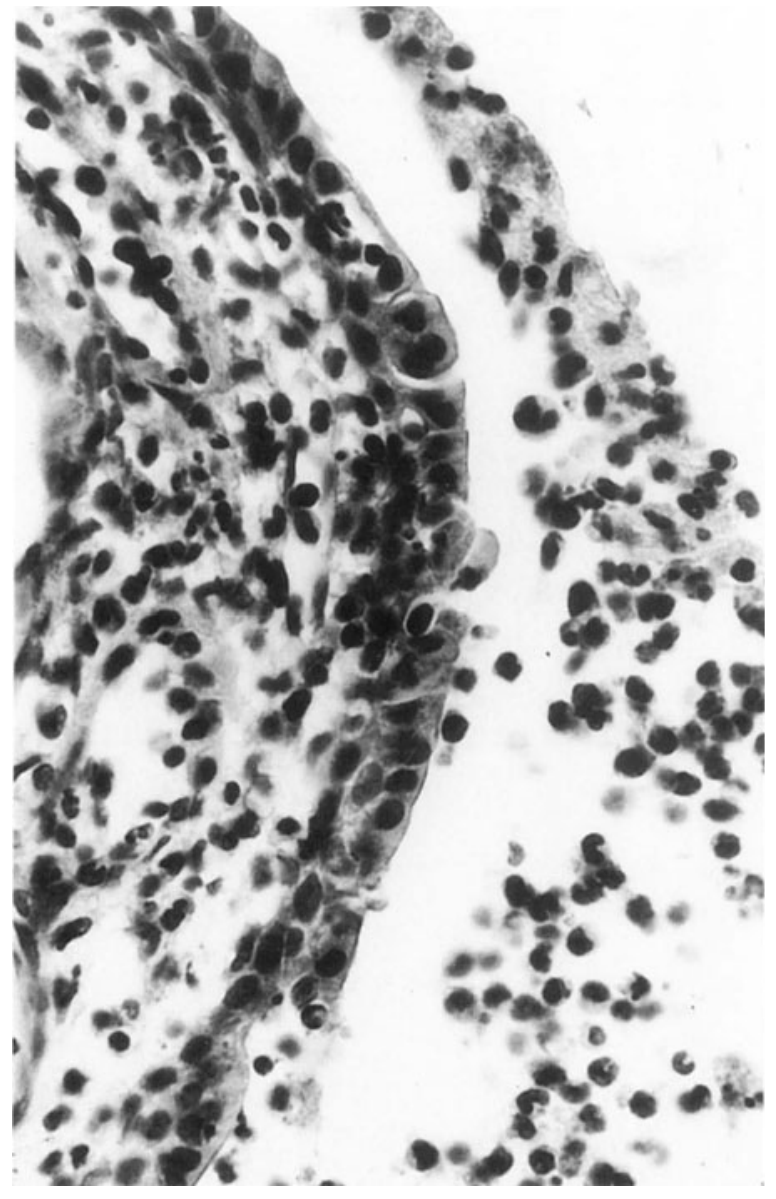

Fig. 163. Ventral turbinate of a rat experimentally infected with rat coronavirus. Much of the epithelium is necrotic and desquamated. Some leukocytes are present in the lumen. $\mathrm{H} \& \mathrm{E}, \times 740$

et al. 1969). Infected epithelial cells have focally dilated cisternae of endoplasmic reticulum and cytoplasmic vesicles which contain spherical dense or hollow cores $60-70 \mathrm{~nm}$ in diameter surrounded by an envelope $80-120 \mathrm{~nm}$ in diameter. The characteristic corona, seen in negatively stained preparations, is not observed by transmission ultramicroscopy.

\section{Differential Diagnosis}

Upper respiratory tract lesions must be distinguished from those caused by Sendai virus, pneumonia virus, Mycoplasma pulmonis, and pathogenic bacteria. Pneumonic changes, which frequently accompany rhinitis caused by Parker's rat coronavirus, Sendai virus, and pneumonia vi- rus, have not been reported in rat coronavirus infection. A careful histopathological examination of the exocrine tissues of the head is usually sufficient to enable one provisionally to diagnose rat coronavirus infection, but rhinotracheitis can precede changes in these tissues.

\section{Biological Features}

Natural History. Rat coronavirus causes acute limited infections; there is no evidence for a carrier state. The virus is highly contagious and is transmitted by aerosol, direct contact, anc fomites. There are two patterns of infection Enzootic infections occur primarily in breeding colonies, where sucklings are passively immune adults are actively immune, and weanlings are a continuous source of susceptible individuals due to waning passive immunity. It is therefore weanlings that generally exhibit clinical signs. Explosive epizootics occur in nonimmune colonies with the highest morbidity in weanlings. Signs are usually transient and consist of intermandibulas and cervical edema, swelling of submaxillary glands, sneezing, and nasal and ocular discharges which are often red-tinged due to a high conten 1 of porphyrin, photophobia, and keratoconjunc. tivitis and its sequelae. Some complications of keratoconjunctivitis, such as glaucoma anc phthisis, cause permanent disfigurement (Jacoby et al. 1979). Subclinical infections are common Extensive host range studies have not been car. ried out but rat coronavirus can experimentally infect mice by the respiratory route (Bhatt et al 1977).

Pathogenesis. Rat coronavirus is epitheliotropic with replication limited to the respiratory trac and certain exocrine tissues of the head and neck It replicates at all levels of the respiratory tract bu produces disease primarily in the upper respira tory tract, where the highest titers are achieved Virus is excreted for 7 days, after which it is cleared, and neutralizing and complement-fixins antibodies appear in the serum (Jacoby et al. 1975 1979).

Etiology. Rat coronavirus (Coronaviridae) is c pleomorphic, enveloped RNA virus with plump pedunculated surface projections (corona). It is approximately $114 \mathrm{~nm}$ in diameter. The virus rep. licates intracytoplasmically and virions are formec 
in cytoplasmic vesicles and endoplasmic reticulum (Jacoby et al. 1979). The virus is closely related antigenically to sialodacryoadenitis virus (Bhatt et al. 1972).

Frequency. Coronavirus infections are common in commercial and institutional rat colonies (Jacoby et al. 1979; Parker et al. 1970). Because of the close antigenic relationship of Parker's rat coronavirus to SDAV seroconversion to both viruses occurs in coronavirus-infected rats. It is therefore difficult to confirm coronavirus infection by serology alone (Bhatt et al. 1972; Jacoby et al. 1979).

\section{Comparison with Other Species}

Coronaviruses are ubiquitous in humans, animals, and birds (Bohl 1981). Although coronaviruses cause respiratory infections in chickens, humans, and rats, SDAV (and to a limited degree Parker's rat coronavirus) is the only coronarvirus that replicates and produces disease in salivary, exorbital, and harderian glands.

\section{References}

Bhatt PN, Percy DH, Jonas AM (1972) Characterization of the virus of sialodacryoadenitis of rats: a member of the coronavirus group. J Infect Dis 126:123-130

Bhatt PN, Jacoby RO, Jonas AM (1977) Respiratory infection in mice with sialodacryoadenitis virus, a coronavirus of rats. Infect Immun 18:823-827

Bohl EH (1981) Coronaviruses: diagnosis of infections. In: Kurstak E, Kurstak C (eds) Comparative diagnosis of viral diseases, vol 4. Academic, New York, chap 7

Innes JRM, Stanton MF (1961) Acute diseases of the submaxillary and harderian glands (sialodacryoadenitis) of rats with cytomegaly and no inclusion bodies. Am $\mathbf{J}$ Pathol 38:455-468

Jacoby RO, Bhatt PN, Jonas AM (1975) Pathogenesis of sialodacryoadenitis in gnotobiotic rats. Vet Pathol 12:196209

Jacoby RO, Bhatt PN, Jonas AM (1979) Viral diseases. In: Baker HJ, Lindsey JR, Weisbroth SH (eds) The laboratory rat, vol 1. Academic, New York, chap 11

Jonas AM, Craft J, Black CL, Bhatt PN, Hilding D (1969) Sialodacryoadenitis in the rat. A light and electron microscopic study. Arch Pathol 88:613-622

Parker JC, Cross SS, Rowe WP (1970) Rat coronavirus (RCV): a prevalent, naturally occurring pneumotropic virus of rats. Arch Virusforsch 31:293-302 